\title{
Emergent endovascular repair in a spontaneous isolated ruptured common iliac aneurysm: an important diagnosis to remember
}

\author{
Enoch Yeung (10 , Adeolu Adeboye, Luke Dombert, Silviu Marica
}

Surgery, Guthrie Robert Packer Hospital, Sayre, Pennsylvania, USA

\section{Correspondence to Dr Enoch Yeung; enot_2001@yahoo.com}

Accepted 28 August 2020

\section{DESCRIPTION}

A 67-year-old man, with a history of hypertension, presented with sudden onset of persistent, diffuse abdominal pain and haemorrhagic shock. The pain was described as a sharp, 7-8 out of 10 pain. There was no other associated symptom. On evaluation, his vital signs were as follows: blood pressure $81 / 50 \mathrm{~mm} \mathrm{Hg}$ on $15 \mathrm{mcg} / \mathrm{kg} / \mathrm{min}$ dopamine, pulse rate $38 \mathrm{bpm}$, respiratory rate 24 breaths/min, $\mathrm{SpO}_{2}$ $98 \%$ and body temperature $97.0^{\circ} \mathrm{F}$. On physical examination, the abdomen was softly distended and tender without guarding or rebound tenderness. Bilateral pedal pulses were equally palpable. The patient did not have any specific clinical or physical signs suggestive of connective tissue diseases such as Ehler-Danlos syndrome. Laboratory data showed haemoglobin of $7.5 \mathrm{~g} / \mathrm{dL}(13.7-17.5 \mathrm{~g} / \mathrm{dL})$, haematocrit $28.8 \%(\mathrm{~N}: 40.1 \%-51 \%)$, creatinine $1.5 \mathrm{mg} /$ dL $(0.8-1.5 \mathrm{mg} / \mathrm{dL})$, blood urea nitrogen (BUN) $17 \mathrm{mg} / \mathrm{dL}(9-20 \mathrm{mg} / \mathrm{dL})$ and lactate $5.6 \mathrm{mmol} / \mathrm{L}$. Contrast-enhanced CT angiography revealed a ruptured left common iliac artery (figure 1). The patient was taken to the operating room immediately for emergent endovascular repair.

Spontaneous rupture of an isolated common iliac artery aneurysm (ICIAA) is a rare vascular pathology; however, it is associated with high mortality of up to $60 \% .^{1}$ As endovascular intervention evolves, primary elective repair for the ICIAA has been reported. ${ }^{2}$ In this case, the patient presented with a ruptured ICIAA with associated haemodynamic instability. Due to the deep pelvic location of the iliac artery, an open surgical approach can be challenging. Given the haemodynamic instability of the patient, an endovascular approach was

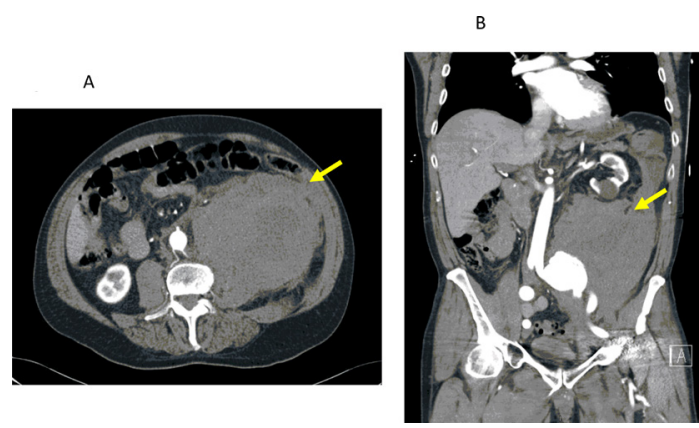

Figure 1 Preoperative CT images. The consecutive haematoma from the ruptured left isolated common iliac artery aneurysm was shown (yellow arrow): (A) Axial view. (B) Coronal view.
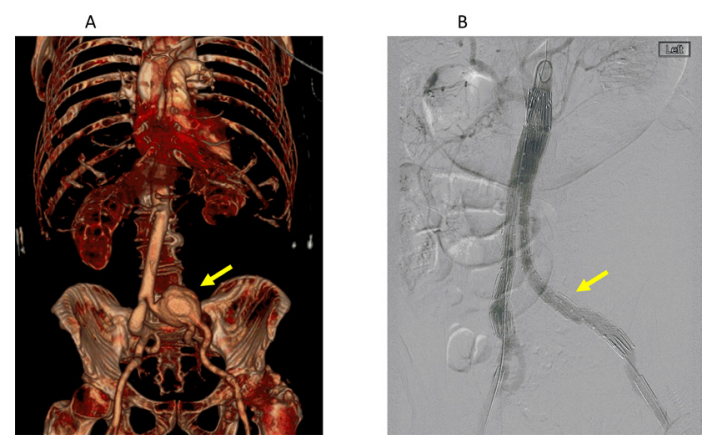

Figure 2 (A) Pretreatment three-dimensional CT. (B) Post endovascular stent graft repair fluoroscopy. There is no extravasation of the contrast outside the endovascular stent graft (yellow arrow).

used to minimise the potential complications from open surgical repair, which would have required general anaesthesia. The intraoperative course was unremarkable using intravenous sedation with monitored anaesthesia care until the ruptured iliac aneurysm has been sealed. A modular bifurcated prosthesis cook zenith graft with two docking stations, which included main body graft, left iliac limb and right iliac limb, was placed. A distal extension limb was then placed to the left external iliac artery (figure 2).

Postoperatively, the patient was transferred to the intensive care unit for close monitoring. His recovery course was unremarkable. He remained neurovascularly intact until the time of discharge on postoperative day 6 .

Endovascular repair of ICIAA has been investigated in the recent years. Buck et al demonstrated that endovascular repair has significantly lower in-hospital mortality, length of stay and complication rate compared with the open approach. ${ }^{3}$ The endovascular treatment for common iliac artery aneurysm, which is located at more than $2 \mathrm{~cm}$ from

\section{Patient's perspective}

The surgical team worked into the early morning to save my life. I laid conscious through much of the procedure, it was clear that their preparedness and teamwork were critical to getting me through this unprecedented time. Going past Hammond Lake, coming up to my house and seeing my children and grandchildren, I realized how great a gift the team had given me. The gift of time to witness life pass. 


\section{Learning points}

- Differential diagnosis of acute onset of abdominal pain in the setting of shock includes ruptured aortic abdominal aneurysm, hollow viscus rupture and common iliac artery aneurysm rupture.

- Endovascular approach is an option for isolated common iliac artery aneurysm rupture if expertise is available.

- Long-term regular follow-up for endoleak is needed after endovascular stent graft treatment.

the aortoiliac bifurcation, is suggested to be treated with endovascular stent graft placement in the ipsilateral common with stent graft placement or embolisation of the internal iliac artery to avoid type 2 endoleak which is retrograde flow to the aneurysms. ${ }^{45}$ A 10 -year follow-up after endovascular stent graft was reported to be safe. ${ }^{6}$ In this article, we reported an uncommon but possibly fatal pathology which was treated with endovascular surgical repair with an optimal outcome. We will closely follow-up the patient on a regular basis for surveillance of endoleak.

Contributors SM led the patient care. SM, AA, LD and EY were involved in the patient care. All were involved in conception and planning of the manuscript. EY led the writing, data collection and literature review. SM, AA, LD and EY reviewed and contributed to the manuscript.

Funding The authors have not declared a specific grant for this research from any funding agency in the public, commercial or not-for-profit sectors.

Competing interests None declared.

Patient consent for publication Obtained.

Provenance and peer review Not commissioned; externally peer reviewed.

\section{ORCID iD}

Enoch Yeung http://orcid.org/0000-0003-3238-4240

\section{REFERENCES}

1 Sandhu RS, Pipinos II. Isolated iliac artery aneurysms. Semin Vasc Surg 2005;18:209-15.

2 Kobe A, Andreotti C, Puippe G, et al. Primary Endovascular Elective Repair and Repair of Ruptured Isolated lliac Artery Aneurysms Is Durable-Results of 72 Consecutive Patients. J Vasc Interv Radiol 2018;29:1725-32.

3 Buck DB, Bensley RP, Darling J, et al. The effect of endovascular treatment on isolated iliac artery aneurysm treatment and mortality. J Vasc Surg 2015;62:331-5.

4 Sakamoto I, Sueyoshi E, Hazama S, et al. Endovascular treatment of iliac artery aneurysms. Radiographics 2005;25 Suppl 1:\$213-27.

5 Dierks A, Sauer A, Wolfschmidt F, et al. Proximal occlusion of unaffected internal iliac artery versus distal occlusion of aneurysmatic internal iliac artery prior to EVAR: a comparative evaluation of efficacy and clinical outcome. Br J Radiol 2017;90:20160527

6 Goksel OS, Gok E, Onalan MA, et al. Endovascular repair of iliac artery aneurysms: a single center experience in 10-Years. Heart Surg Forum 2019;22:E088-91.

Copyright 2020 BMJ Publishing Group. All rights reserved. For permission to reuse any of this content visit https://www.bmj.com/company/products-services/rights-and-licensing/permissions/

BMJ Case Report Fellows may re-use this article for personal use and teaching without any further permission.

Become a Fellow of BMJ Case Reports today and you can:

- Submit as many cases as you like

Enjoy fast sympathetic peer review and rapid publication of accepted articles

- Access all the published articles

- Re-use any of the published material for personal use and teaching without further permission

Customer Service

If you have any further queries about your subscription, please contact our customer services team on +44 (0) 2071111105 or via email at support@bmj.com.

Visit casereports.bmj.com for more articles like this and to become a Fellow 